Babes in the Darkling Wood

By H. G. Wells. Pp. 399. (London: Martin Secker and Warburg, Ltd., 1940.) 9s. 6d. net.

NR. H. G. WELLS has done much to raise the 1 prestige of science among the people. Here, at the age of seventy-four, he is still trying, with the intensest energy, to communicate to the generality of mankind the implications of science. In his latest book he has used the technique of the novel of ideas to represent the attitude of young people to current events, and suggest what line they should pursue in the light of modern psychology. The ideas of Pavlov and Freud are discussed at length through the dialogues of the characters, but though an impression of their importance is conveyed successfully, they are not very clearly explained.

Mr. Wells recommends that the problem of modern life should be approached in the spirit of the sculptor who contemplates a block of uncarved marble. The possibilities in it should be conceived by a flexible imagination, and all should hack away at it until they have carved out the figure of society that they desire. The advantage of this approach is that it precludes doctrinaire planning. The sculptor is unable to make a finished preliminary draft of the three-dimensional end at which he aims, and must trust to the guidance of intelligent imagination in the course of his work. But this does not prevent him from having some drafts, and a model in his imagination which undergoes continual adaptation and is therefore living. Though Mr. Wells tends to become ever more discursive, his belief in the future and continual wrestlings with the present are still a major inspiration.

J. G. Crowther.

\section{Qualitative Organic Chemistry}

By Neil Campbell. Pp. ix +213 . (London: Macmillan and Co., Ltd., 1939.) 8s. 6d.

7 HE isolation of pure organic compounds and the common criteria of purity are first discussed. An account of preliminary tests for classifying the unknown compound is then followed by details of more specialized confirmatory tests. Next, a review of the properties of various organic types is associated with information on the choice of derivatives suitable for the identification of specific members of each class. Practical methods for preparing thirty-two kinds of these derivatives are then given, this chapter in particular being provided with many references to the literature. A short note on the examination of mixtures concludes the first part (100 pp.) of the book. The second part $(98 \mathrm{pp}$.) consists of a series of classified lists of various groups of organic compounds, with summaries of the properties of the individual substances and useful derivatives. A short bibliography and indexes are also included.

This is a thoroughly sound and up-to-date little book; besides acting as a handy and dependable vade mecum in the laboratory, it will stimulate its users to refer to standard works and original papers, and in general to turn to full account the educative value of this important field of practical organic chemistry.
L'Origine des cellules reproductrices et le probleme de la lignée germinale

Par Prof. L. Bounoure. (Collection des actualités biologiques.) Pp. xii + 272. (Paris : Gauthier-Villars, 1939.) 100 francs.

WHILE, perhaps particularly in Great Britain, most of the recent work on the reproductive cells has been concerned with the intimate structure of the chromosomes and their behaviour during fertilization and division, and with the consideration of certain extra-nuclear structures, Golgi bodies, ete., the questions of the history of the germ cells themselves and their relationship to the corresponding cells of their parents have continued to occupy the attention of zoologists. The time was ripe, therefore, for a review of these lines of research, and it has been provided by Prof. L. Bounoure, who is well known for a succession of papers in this field. Previous workers, including Jäger, who first used the expression "Continuität des Keimplasmas" in 1877 and not Weismann as is generally believed, had put forward speculative theories on the subject. The first to realize the problem definitely and to investigate it scientifically was M. Nussbaum in 1880 . The present volume, after a historical introduction, reviews the whole subject of the origin of the germ cells and germinal continuity in an exhaustive manner throughout the animal kingdom. The account is fully documented by quotations of the crucial statements and contains discussions of the theoretical questions involved. It is a most useful and readable publication.

\section{Special Surgery in Wartime}

By D. W. C. Northfield, Dr. Douglas McAlpine, Dr. V. Zachary Cope, T. Holmes Sellors, A. B. Wallace. (The Practitioner Booklets.) Pp. vii +74. (London: Eyre and Spottiswoode (Publishers), Ltd., 1940.) $6 s$. net.

7 HIS little book provides a concise but comprehensive description of the most important types of war injury. Mr. D. W. C. Northfield has given an excellent clarification of the relations between the clinical picture and the underlying pathological changes in head injuries, and his summarization of the treatment is most helpful. Dr. Douglas McAlpine has surveyed spinal cord lesions well, but although he quotes Watson Jones, he has failed to emphasize the types of injury in which it is dangerous to reduce the deformity by manipulation and in which open reduction is necessary to prevent either the onset or progression of a paraplegia.

Mr. Zachary Cope and Mr. Holmes Sellors, on abdominal and chest injuries, should be read by all.

The treatment of burns at the moment is undergoing startling changes, and, although Mr. A. B. Wallace has written along the orthodox lines, his article will quite soon be out of date. For example, he still recommends tannic acid in the treatment of burns of the hands, and no mention is made of more modern methods of treating third degree burns by saline baths, irrigation in Bunyan-Stannard bags, etc.

Finally, a most useful appendix summarizes the uses of the sulphonamides in war surgery. 